\title{
Clozapine generates obsessive compulsive disorder-like behavior in mice
}

\author{
Shinwon Kang ${ }^{1 \dagger}$, Hyun Jong Noh ${ }^{1 \dagger}$, Soo Hyeon Bae ${ }^{2 \dagger}$, Yong-Seok Kim³, ${ }^{3,4}$ Hogun Lew ${ }^{1}$, Jisoo Lim , Se Joo Kim
} Kyung Sue Hong ${ }^{6}$, Jong-Cheol Rah ${ }^{3,4^{*}}$ and Chul Hoon Kim ${ }^{1,7^{*}}$ (D)

\begin{abstract}
Clozapine is thought to induce obsessive compulsive symptoms (OCS) in schizophrenic patients. However, because OCS are often comorbid with schizophrenia regardless of clozapine treatment, it remains unclear whether clozapine can generate OCS de novo. Thus, it has been difficult to establish a causal link between clozapine and OCS in human studies. To address this question, we asked whether chronic treatment with clozapine can induce obsessive compulsive disorder (OCD)-like behavior in mice. We injected mice with long-term continuous release pellets embedded with clozapine four times at 60-day intervals and then monitored the mice for signs of OCD-like behavior up to $40 \mathrm{wk}$. of age. We found clozapine increases grooming behavior as early as $30 \mathrm{wk}$. of age. We also investigated the effect clozapine on grooming behavior in Sapap3 knockout (KO) mice, which are a well-known animal model of OCD. In Sapap3 heterozygous KO mice, clozapine increases grooming behavior much earlier than in wild-type mice, suggesting a clozapine-OCD gene interaction. Fluoxetine, which is often used in the treatment of OCS and OCD, reduced the grooming behavior induced by clozapine. These data demonstrate that chronic clozapine treatment can generate OCD-like behavior in mice and support the hypothesis that clozapine produces de novo OCS regardless of schizophrenia status.
\end{abstract}

Antiserotonergic second generations antipsychotics (SGA) like clozapine, risperidone, and olanzapine are widely used in the treatment of schizophrenia. In contrast to other SGA that primarily work on dopamine receptors, they have pronounced antiserotonergic properties [1]. A series of clinical reports have suggested that the antiserotonergic SGA may also increase the occurrence of OCS in patients with schizophrenia [2-4]. But because schizophrenia and OCS are often comorbid, this effect remains controversial. Moreover, even if the antiserotonergic SGA do promote OCS, it is difficult to tell whether this is de novo OCS or simply an unmasking or exacerbation of pre-existing OCS.

\footnotetext{
* Correspondence: jcrah@kbri.re.kr; kimhoon@yuhs.ac

†'Shinwon Kang, Hyun Jong Noh and Soo Hyeon Bae contributed equally to this work.

${ }^{3}$ Korea Brain Research Institute, Daegu 41068, South Korea

'Department of Pharmacology, BK21 PLUS Project for Medical Science, Brain Research Institute, Yonsei University College of Medicine, Seoul 03722, South Korea

Full list of author information is available at the end of the article
}

There are several lines of indirect evidence that support a causal relationship between antiserotonergic SGA and OCS in schizophrenic patients [4]. First, the prevalence of OCS increased after market approval of the first SGA [4]. Second, OCS are more prevalent in schizophrenic patients treated with antiserotonergic SGAs $[5,6]$. Third, OCS severity is positively correlated with antiserotonergic SGA treatment duration and dose size [7]. Although these lines of evidence strongly suggest a link, more prospective cohort studies and studies using disease-relevant animal models are warranted to fully address this question.

Here, we used normal mice (B6J) to determine whether clozapine can induce de novo OCD-like symptoms. Clozapine is the antiserotonergic SGA most commonly associated with OCS in schizophrenia. Because the onset time of OCS in schizophrenic patients treated with clozapine is 1 to 96 months (median 19.5 months) [6], we decided to use specially designed clozapine pellets that slowly and continuously release clozapine for

(c) The Author(s). 2020 Open Access This article is licensed under a Creative Commons Attribution 4.0 International License which permits use, sharing, adaptation, distribution and reproduction in any medium or format, as long as you give appropriate credit to the original author(s) and the source, provide a link to the Creative Commons licence, and indicate if changes were made. The images or other third party material in this article are included in the article's Creative Commons licence, unless indicated otherwise in a credit line to the material. If material is not included in the article's Creative Commons licence and your intended use is not permitted by statutory regulation or exceeds the permitted use, you will need to obtain permission directly from the copyright holder. To view a copy of this licence, visit http://creativecommons.org/licenses/by/4.0/ The Creative Commons Public Domain Dedication waiver (http://creativecommons.org/publicdomain/zero/1.0/) applies to the data made available in this article, unless otherwise stated in a credit line to the data. 
60 days. We treated mice (B6J) with clozapine for 240 days by implanting the first clozapine pellet at $12 \mathrm{wk}$. of age with follow-up injections at 60-day intervals (Fig. 1a, see Additional file 1 for the detailed methods). When we measured blood concentration of clozapine 10 days after injection, we found evidence of sustained maintenance of plasma clozapine concentrations (see Additional file 2: Figure S1A). In mice at 15, 20, 30, and 40 wk. of age, we recorded $2 \mathrm{~h}$ of grooming behaviors using a video camera. Two independent experimenters then manually scored grooming duration and bout number. We found clozapine increases grooming time in wild-type mice

A

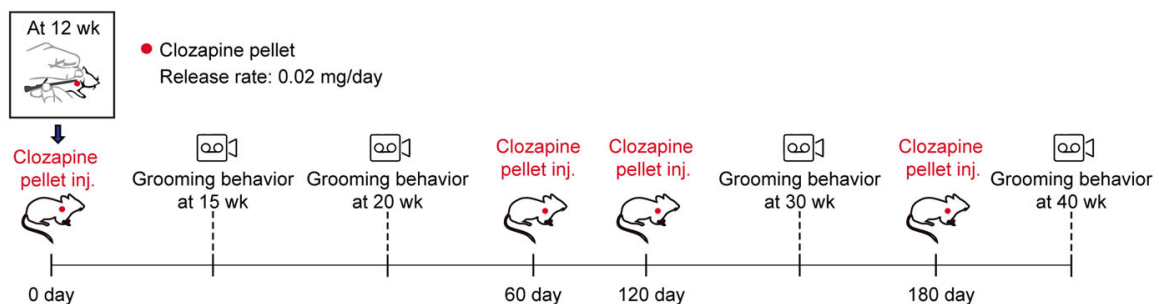

B

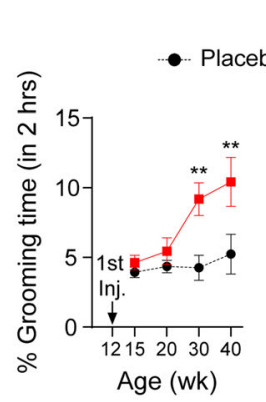

WT

- Clozapine

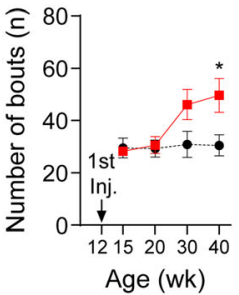

c

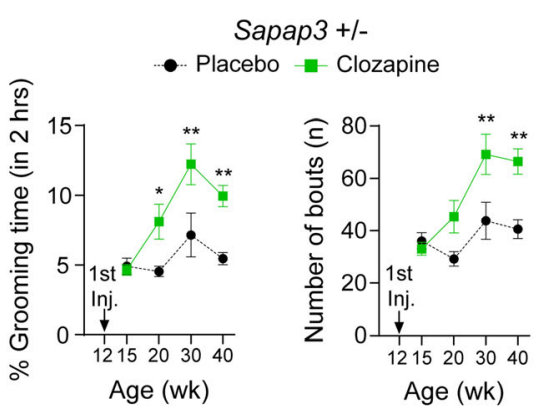

$\mathrm{D}$

Fluoxetine treatment

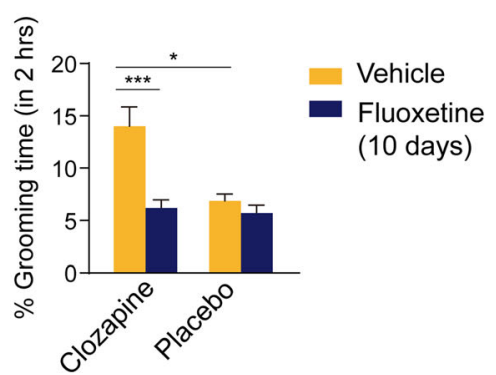

Fig. 1 Clozapine-treated mice showed over grooming behavior. a Schematic diagram of experimental procedure. Wild-type and Sapap $3^{+/-}$adult mice were administered with either clozapine or placebo for 28 wks, starting from age of 12 wk. b Clozapine-treated wild-type mice showed increased repetitive grooming behavior. Mice were injected with clozapine or placebo pellets at the age of 12 wk. with 60-day interval pellet injection. Mice behavior was recorded for $2 \mathrm{~h}$ and analyzed at the age of 15, 20, 30, and 40 wk. (Two-way RM ANOVA, main effect of treatment; $F(1,16)=9.161, p=0.008$, main effect of time; $F(3,48)=5.525, p=0.002$, treatment $x$ time interaction; $F(3,48)=2.981, p=0.04$, $\left.{ }^{* *} p<0.01\right)($ left). Grooming lasted more than $3 \mathrm{~s}$ was counted as a bout (Two-way RM ANOVA, main effect of treatment; $F(1,16)=6.073, p=0.025$, main effect of time; $F(3,48)=3.491, p=0.023$, treatment $x$ time interaction; $\left.F(3,48)=2.674, p=0.058,{ }^{*} p<0.05\right)$ (right). c Clozapine-treated Sapap $3^{+/-}$mice showed increased repetitive grooming behavior earlier than clozapine-treated wild-type mice. Sapap $3^{+/-}$mice were injected with clozapine or placebo pellets at the age of 12 wk. with 60-day interval pellet injection. Mice behavior was recorded for $2 \mathrm{~h}$ and analyzed at the age of 12,15 , 20, 30 and 40 wk. (Two-way RM ANOVA, main effect of treatment; $F(1,12)=16.99, p=0.01$, main effect of time; $F(3,36)=10.12, p<0.001$, treatment $x$ time interaction; $F(3,36)=3.348, p=0.03,{ }^{*} p<0.05,{ }^{* *} p<0.01$ ) (left). Numbers of grooming bouts were counted from $2 \mathrm{~h}$ video-recording of grooming behavior. Grooming bouts were increased in Sapap ${ }^{+/-}$mice after 18 wk. of clozapine treatment (Two-way RM ANOVA, main effect of treatment; $F(1,12)=14.16, p=0.003$, main effect of time; $F(3,36)=11.17, p<0.001$, treatment $x$ time interaction; $F(3,36)=4.095, p=0.013$, ** $p<$ 0.01 ) (right). $\mathbf{d}$ Fluoxetine treatment ameliorated overgrooming behavior in clozapine-treated wild-type mice (Two-way ANOVA, main effect of fluoxetine treatment; $F(1,6)=21.75, p=0.003$, main effect of clozapine treatment; $F(1,6)=9.27, p=0.023$, fluoxetine treatment $x$ clozapine treatment interaction; $\left.F(1,6)=7.071, p=0.038,{ }^{*} p<0.05,{ }^{* * *} p<0.001\right) n=4$ per group. All data are presented as means \pm SEM 
beginning at $30 \mathrm{wk}$. of age (18 wk. after 1st clozapine pellet injection) (Fig. 1b, left). We also found mice treated with clozapine pellets for 40 wks engage in more grooming bouts (Fig. 1b, right). We did not see any change in weight between clozapine- and placebotreated mice (see Additional file 2: Figure S1B). In human studies, genetic interactions of SAPAP3 and SLC1A1 gene variants are predictive of antiserotonergic SGA-induced OC symptoms [8]. The homozygous deletion of Sapap3 in mice induces grooming behavior that is severe enough to develop facial and neck skin lesions [9]. Thus, we also tested the effect of clozapine on OCD-like behavior in Sapap3 knockout mice. We started to observe the development of skin lesions from $20 \mathrm{wk}$. in homozygous mice and this reached $100 \%$ penetration by the age of $40-60$ wk. Clozapine does not accelerate the development of skin lesions in these Sapap3 homozygous KO mice, probably because the grooming behavior is already so severe (see Additional file 2: Figure S1C). Sapap3 heterozygous KO mice, in contrast, do not show increased grooming behavior or skin lesions [9]. Interestingly, we found clozapine induces grooming behavior in Sapap3 heterozygous $\mathrm{KO}$ mice earlier than in wild-type mice (Fig. 1c). We next tested whether fluoxetine, a selective serotonin reuptake inhibitor, can reduce the grooming behavior induced by chronic clozapine treatment. As shown in Fig. 1d, we observed that 10 days of daily intraperitoneal fluoxetine injections into mice administered clozapine for 30 wks significantly reduces their grooming time. This suggests 5-HT signaling is involved in the pathogenesis of clozapineinduced OCS and that OCD-like behavior in mice responds to the therapeutic agents typically used in humans.

In this study, we demonstrated for the first time that chronic clozapine administration can induce OCD-like behavior in mice. We provide new data on the long-standing question of whether clozapine induces de novo OCS even in normal conditions. There are several reasons this mouse model is useful for the study of clozapine-induced OCS. First, as in humans [6], significant time is required for the induction of OCD-like behavior after clozapine administration in mice. Second, this model meets all the criteria of validity for animal models of psychiatric disorders [10]; the mouse model shows OCD-like behavior (face validity), has clozapine as an inducer (construct validity), and responds to fluoxetine (predictive validity). Lastly, we confirmed in Sapap3 KO mice a clear interaction between clozapine and a gene linked to clozapineinduced OCS in humans [8].

While clozapine is the only antipsychotic agent indicated for treatment-resistant schizophrenia [1], the occurrence of OCS after initiation of clozapine treatment is associated with additional functional impairment and poor prognosis of the disease [4]. This animal model will provide a new opportunity for researchers trying to develop effective antipsychotics that do not promote OCS as a side effect. This model will also make it easier to study the molecular and circuit mechanisms contributing to OCS from a translational perspective. The therapeutic effect of fluoxetine we observed suggests the involvement of $5-\mathrm{HT}$ receptors $\left(5-\mathrm{HT}_{1 \mathrm{~A}}, 5-\mathrm{HT}_{2 \mathrm{~A}}\right.$, and $5-$ $\mathrm{HT}_{2 \mathrm{C}}$ ), which are thought to be targets of clozapine [1]. The association of SLC1A1 polymorphism with symptom occurrence in human also hints at a potential role for glutamate neurotransmission [11]. It seems that the effects of glutamate-related genes on clozapine-induced OCS represent a genetic predisposition (or susceptibility) rather than playing a causative role. Fluoxetine also inhibits compulsive grooming behavior of Sapap3 homozygous $\mathrm{KO}$ mice [9], but only when administered over a long period of time. This suggests that acute changes in serotonin levels do not directly suppress compulsive behaviors. Instead, selective serotonin uptake inhibitors may alter clozapine-induced derangement in OCDrelated neural substrates like the cortico-striatothalamo-cortical circuit $[12,13]$. The relative importance and contribution of each of these remains unclear. Further study of the actions of clozapine in this new mouse model will improve our understanding of the pathogenesis of OCS and accelerate the development of antipsychotics that lack OCS-inducing side effects.

\section{Supplementary information}

Supplementary information accompanies this paper at https://doi.org/10. 1186/s13041-020-00621-5.

Additional file 1. Raw data of the tested parameters in wild-type.

Additional file 2: Figure S1. A Plasma clozapine concentration 10 days after clozapine pellet injection. Placebo-injected age-matched mice were used as controls (Student $t$ test, ${ }^{* *} p<0.01$ ). $n=4$ per group. B Body weight change of clozapine- or placebo-treated mice in wild-type and Sapap3+/- mice. There was no significant difference between clozapineand placebo-treated mice. $n=5-6$ per group C Survival curve of skin lesion development in Sapap $3^{-/-}$mice (left). Sapap $3^{-/-}$mice have neck and facial skin lesions (white arrows). $n=7-12$ per group. All data are presented as means \pm SEM

Additional file 3. Sapap3-/- mice.

Abbreviations

OCD: Obsessive compulsive disorder; OCS: Obsessive compulsive symptoms; WT: Wild-type; KO: Knockout; SEM: Standard error of the mean

\section{Authors' contributions}

CHK, JR, SJK, and KSH conceptualized and designed the research. SK, HJN, YK, $H \mathrm{~L}$, and $\mathrm{JL}$ conducted the behavioral experiments. SHB conducted the drug concentration analysis. CHK, JR, SHB, SJK, KSH analysed and interpreted the data. CHK, JR, and SK prepared the manuscript. All authors read and approved the final manuscript. 


\section{Funding}

This work was supported by grants from the National Research Foundation of Korea (NRF) funded by the Korean government (MSIT) (NRF2017M3C7A1048090, NRF-2018R1A5A2025079, NRF-2019R1A2C3002354) and from the Korea Health Technology R\&D Project through the Korea Health Industry Development Institute (KHIDI), funded by the Ministry of Health \& Welfare, Republic of Korea (HI15C0626).

\section{Availability of data and materials}

All data and materials are available upon requests.

\section{Ethics approval and consent to participate}

All animal experiments were performed in compliance with guidelines approved by the Institutional Animal Care and Use Committee (IACUC) of Yonsei University Health System (reference number: 2018-0278).

\section{Consent for publication}

Not applicable.

\section{Competing interests}

The authors declare that they have no competing interests.

\section{Author details}

'Department of Pharmacology, BK21 PLUS Project for Medical Science, Brain Research Institute, Yonsei University College of Medicine, Seoul 03722, South Korea. ${ }^{2}$ Q-fitter, Inc., Seoul 06591, South Korea. ${ }^{3}$ Korea Brain Research Institute, Daegu 41068, South Korea. ${ }^{4}$ Department of Brain and Cognitive Sciences, DGIST, Daegu 42988, South Korea. ${ }^{5}$ Department of Psychiatry, Yonsei University College of Medicine, Seoul 03722, South Korea. ${ }^{6}$ Department of Psychiatry, Sungkyunkwan University School of Medicine, Samsung Medical Center, Seoul 06351, South Korea. ${ }^{7}$ Severance Biomedical Science Institute, Yonsei University College of Medicine, Seoul 03722, South Korea.

Received: 13 February 2020 Accepted: 12 May 2020

Published online: 29 May 2020

\section{References}

1. Meltzer HY. Update on typical and atypical antipsychotic drugs. Annu Rev Med. 2013;64:393-406.

2. Baker RW, Chengappa KN, Baird JW, Steingard S, Christ MA, Schooler NR Emergence of obsessive compulsive symptoms during treatment with clozapine. J Clin Psychiatry. 1992;53:439-42.

3. de Haan L, Linszen DH, Gorsira R. Clozapine and obsessions in patients with recent-onset schizophrenia and other psychotic disorders. J Clin Psychiatry. 1999;60:364-5.

4. Schirmbeck F, Zink M. Comorbid obsessive-compulsive symptoms in schizophrenia: contributions of pharmacological and genetic factors. Front Pharmacol. 2013:4:99.

5. Poyurovsky M, Weizman A, Weizman R. Obsessive-compulsive disorder in schizophrenia: clinical characteristics and treatment. CNS Drugs. 2004;18: 989-1010.

6. Lim M, Park DY, Kwon JS, Joo YH, Hong KS. Prevalence and clinical characteristics of obsessive-compulsive symptoms associated with atypical antipsychotics. J Clin Psychopharmacol. 2007;27:712-3.

7. Schirmbeck F, Esslinger C, Rausch F, Englisch S, Meyer-Lindenberg A, Zink M. Antiserotonergic antipsychotics are associated with obsessive-compulsive symptoms in schizophrenia. Psychol Med. 2011:41:2361-73.

8. Ryu S, Oh S, Cho EY, Nam HJ, Yoo JH, Park T, Joo YH, Kwon JS, Hong KS. Interaction between genetic variants of DLGAP3 and SLC1A1 affecting the risk of atypical antipsychotics-induced obsessivecompulsive symptoms. Am J Med Genet B Neuropsychiatr Genet. 2011; 156B:949-59.

9. Welch JM, Lu J, Rodriguiz RM, Trotta NC, Peca J, Ding JD, Feliciano C, Chen M, Adams JP, Luo J, et al. Cortico-striatal synaptic defects and OCD-like behaviours in Sapap3-mutant mice. Nature. 2007;448:894-900.

10. Nestler EJ, Hyman SE. Animal models of neuropsychiatric disorders. Nat Neurosci. 2010;13:1161-9.

11. Kwon JS, Joo YH, Nam HJ, Lim M, Cho EY, Jung MH, Choi JS, Kim B, Kang $\mathrm{DH}, \mathrm{Oh} \mathrm{S}$, et al. Association of the glutamate transporter gene SLC1A1 with atypical antipsychotics-induced obsessive-compulsive symptoms. Arch Gen Psychiatry. 2009;66:1233-41.

12. Ahmari SE, Spellman T, Douglass NL, Kheirbek MA, Simpson HB, Deisseroth K, Gordon JA, Hen R. Repeated cortico-striatal stimulation generates persistent OCD-like behavior. Science. 2013;340:1234-9.

13. Ahmari SE, Dougherty DD. Dissecting OCD circuits: from animal models to targeted treatments. Depress Anxiety. 2015;32:550-62.

\section{Publisher's Note}

Springer Nature remains neutral with regard to jurisdictional claims in published maps and institutional affiliations.
Ready to submit your research? Choose BMC and benefit from:

- fast, convenient online submission

- thorough peer review by experienced researchers in your field

- rapid publication on acceptance

- support for research data, including large and complex data types

- gold Open Access which fosters wider collaboration and increased citations

- maximum visibility for your research: over $100 \mathrm{M}$ website views per year

At BMC, research is always in progress.

Learn more biomedcentral.com/submissions 